\title{
Social Media as a Critical Reading Lighters Students based in Islamic Values
}

\author{
Oktarina Puspita Wardani ${ }^{1}$, Subyantoro ${ }^{2}$, Fathur Rokhman ${ }^{3}$, Ida Zulaeha ${ }^{4}$ \\ Universitas Islam Sultan Agung ${ }^{1}$ \\ Universitas Negeri Semarang ${ }^{1,2,3,4}$ \\ \{oktarinapw@unissula.ac.id¹, bintoro@mail.unnes.ac.id², fathurrokhman@mail.unnes.ac.id ${ }^{3}$, \\ idazulaeha@mail.unnes.ac.id $\left.{ }^{4}\right\}$
}

\begin{abstract}
The era of the digital age makes social media as reading material for today's millennial students. Social media are able to inspire enthusiasm in students' critical reading, so as to be able to analyze issues concerning Islam. The purpose of this study is that students can improve critical reading based on Islamic values through social media. The research method used is a descriptive analytical method. Sources of research data were obtained from ten students. The data werw obtained in the form of student questionnaire results. Data collection techniques through a questionnaire. The data analysis technique uses competent listening. Various social media are able to increase student interest in reading. Social media is one tool that is able to disseminate information to the reader so as to establish the criticality of students to understand the text which has Islamic values. Some students are able to critically analyze information from social media related to Islamic values. However, some information is sometimes accepted without the due process of critical reading.
\end{abstract}

Keyword: Critical Reading, Islamic Values, Social Media

\section{Introduction}

Today's social media is very easy to access through each person's software. These devices are usually carried everywhere, so they can be accessed anytime and anywhere. Like Siddiqui and Singh social media is a computer feature that allows someone to share ideas, videos, pictures, information and do many things [1]. In times of a pandemic like this, social media is very important to be used by the public, from educators to the business world. The faster dissemination of information through social media is able to maximize the role of social media.

Interest in social media makes a person able to obtain and exchange information. Someone will feel that social media is an alternative to finding information that is currently being discussed. In the field of education, social media can make it easier for students to get information and communicate with other academics. Another function of social media is for entertainment. The need for entertainment makes students take advantage of the role of social media in supporting their enjoyment. This is also accompanied by concerns being complacent in terms of duration of use and user behavior. The difference in boundaries regarding private 
space and public space between each user is a negative effect that may arise as a result of the use of social media[2].

Easily accessible social media pages include Facebook, Twitter, Instagram, Youtube and other. The mass media are able to be used by students well, but are were also negative things about it. The negative thing that arises when there is no filter to access it is the threat of harm to the user. So it takes things that are able to filter or hold users from accessing it. Opinion on social media is able to lead public opinion, so that social media users must have skills in critical reading. The very fast and wide dissemination of information in cyberspace can cause a polemic that can break the unity of the nation. So big is the role of social media in taking advantage of the situation that is currently being discussed for public consumption.

Responding to these things, students can take advantage of critical reading in obtaining information on social media. Students can look for comparable information they get on other social media. Students are able to reduce the spread of hoaxes and filter the information they get. This makes students more critical in terms of responding to information that comes out of social media that is not necessarily reliable.

Things that can be done by students in critical reading are described by Agustina , that a reader must go through three steps first then reading, the reader thinks about the problems and facts contained in the reading. Second, readers analyze the information they read, three readers make judgments when reading [3]. In line with Nurhadi (2009), that critical reading is an activity to critically process reading to get a thorough understanding of the contents of the reading, followed by a firm attitude towards the author's ideas [4].

Critical reading is a skill needed by students today. Information technology that develops rapidly requires readers to be increasingly critical in responding to the information obtained. Reading material contained in social media today is very diverse with their respective goals. Information from social media today is able to influence a person's views, persuade him to believe certain things. In line with what Ahuja and Ahuja stated, critical reading is the application of a critical thinking process to reading. The activities involved in reading criticism are high-level cognitive processes. Readers are required to apply analytic, synthetic, and evaluative thought processes [5].

The role of social media can also provide information about Islam. The use of social media is able to spread knowledge about Islam to readers or the Muslim community. The use of social media provides for the concept of tawhid and faith.. As the word of Allah SWT.

$\mathrm{O}$, people who have believed! If a wicked person comes to you with news, then investigate (to determine) the truth, so that you do not inflict on people a thing that is not desired because of your ignorance (about it) so that it makes you regret what you have done. (6)

(Surah Al-Hujurat, 49: 6)

Social media is clearly capable of playing an important role in providing information to Islamic society. The public is asked to find the truth of all information that comes from various social media. This is done to minimize the chance of believing false information that can be justified. Without clear evidence on information on social media, it can lead to divisions between religions and fellow Muslims. Thus, mass media users must have a big responsibility so that human life can coexist with one another.

The purpose of this research is to improve the practices of critical reading skill in response to information obtained from social media based on Islamic values. Students are able to practice their critical reading skills by utilizing social media. Students will get entertainment on social media, as well as being able to take steps in critical reading. Students do one thing but have many goals, get entertainment, information and improve their reading skills. Thus, 
students are able to get used to not trusting the information they get from social media directly.

Previous research articles by Sulthan and Istiyanto which discussed social media literacy models for students. The results reveal the findings of the UNSOED student social literacy model based on the Potter literacy media model. Students using social media according to the needs and characteristics of existing social media. Students are able to exchange information negative and positive impacts regarding deviations in the use of social media. However, social media is still used because it has become a daily necessity [6].

The knowledge gap is divided into two ways. First, presenting the first literacy design of collaborative computer support for critical reading and prioritizing student evaluations of the benefits and drawbacks associated with LA WiREAD which indicate potential dangers. This article describes the pedagogical complexity of considering learners as a critical stakeholder group [7]. Social media literacy is able to create a society with an informative and knowledge base. Social media literacy is strived to form a critical society in running social media. Social media literacy material must be included in the main material in every social media literacy workshop. This is found in Ganggi's research which explains three main subjects of social media literacy, among others, (1) think before posting, (2) what to post and when to do it, (3) how to find your post [8].

Ibda's research in discussed improving the critical reading skills of MI teachers by reading articles. MI teachers are required to be "literate" and have the ability to read critically so that they are not easily provoked by unsure news. One way to improve teacher critical reading is the metal movement, which requires teachers to use scientific work patterns to adapt to their respective disciplines [9]. Ghofur and Raharjo reveal that the use of social media applications in the SETS and 5E approaches helps complete the learning experience to be more concrete, so that students are helped in terms of discussion, reading and practice [10].

Concluding from several previous studies, the novelty of this study is social media as a tool to practice critical reading skills. Someone capable of reducing indifference to the truth of the information on social media that wants to find the truth in fact. Thus, the information obtained accustoms itself to filtering.

\section{Method}

The research method used is a descriptive analytical method. This research method will describe the data obtained, then the data is analyzed in depth. The data obtained in the study were the results of interviews and student questionnaires. The research data sources were obtained from ten students. The research instrument was in the form of a questionnaire and the researcher himself. The technique of collecting data through a questionnaire. The questionnaire was distributed to ten students. The questionnaire is open. Other supporting data is interviews with ten students. The data analysis technique used the technique of engaging in listening proficiently. The researcher listens to each argument given by the respondent. The results of the questionnaire and interview were described and concluded.

\section{Results and Discussion}

The results of the study found six levels in critical reading. At the first level, students have the skills to interpret information. The second level students are able to analyze information. 
At the third level, students have skills in inferencing. At the fourth level students are able to evaluate an infoemasi. In the fifth stage, students have skills in explanation. The last stage, students are able to relegate themselves to information.

Social media is a way for some people to introduce something and provide information according to their respective goals. Social media is used by students on a daily basis to establish communication, find information, buy and sell as well as things that have a purpose. Students maximize the ins and outs of the social media applications used to increase knowledge. Students carry out critical reading activities in accessing social media. Students are able to create awareness of critical attitudes towards information. Six levels were found in stages in critical reading [11].

\section{a) Interpretation Skills}

Students are able to understand broad meaning in various events. Students are able to formulate categories in various situations and describe situations confidently from their respective points of view. Students are able to explain the meaning by detecting the choice of language used in order to see the objectives and values contained in the information on social media, as well as explaining the relationship between the choice of language used by the author and the objectives the writer wants to convey. Students are also able to classify meanings by paraphrasing information on social media and then describing them in response to the goals, values and views to be conveyed.

Students must have the ability to focus on something. When getting certain information, student must focus on that information. The ability to focus, students carry out activities focused on the activities intended by the author. The data found that ten students were able to focus on the information provided by the author. So, students have done critical reading activities.

\section{b) Analysis Skills}

Analysis skills require readers to identify and link questions, concepts, statements and descriptions so that they can be expressed through beliefs, opinions and judgments. Students are able to determine the implicit intent conveyed by the author on the social media they read. Students compare the ideas or concepts conveyed by the author with concepts from other information which has the same theme. Furthermore, students are able to identify existing problems and determine the relationships between the divisions. At these stage students are able to argue for or against and express reasons for supporting or opposing. The data has found that all the respondents (students) performed the analysis skills-stage. They are able to analyze news that states the truth or news that states untruth. This is conveyed when they have arguments to support or not support the information conveyed on social media that has been read.

\section{c) Skills-Inference}

Inferencing skills include identifying the parts needed to draw a reasonable conclusion, making hypotheses, and considering relevant information. After students identify information on resistance to analyzing skills, students are required to be able to draw conclusions appropriately supported by relevant evidence. After collecting evidence, it is followed by considering the points by formulating supporting evidence with the statements obtained. At 
this stage, students are able to formulate alternative solutions to problems with various possibilities. The possibilities that are obtained can produce good and bad consequences, the policies and beliefs that are obtained. The data found that some students were able to make steps in at this stage. But some still had to repeat several times to gain confidence. This can happen because you have to gather facts that can be formulated into a plausible hypothesis.

\section{d) Evaluation Skills}

Information skill is a skill to gain credibility for a statement based on a belief or argument. Students are able to judge the credibility of facts and assess accountable arguments. What factors are able to influence the emergence of opinions and views obtained. This can be conveyed by revealing weaknesses in the opinion obtained from this information. The weaknesses that are obtained can be used to support arguments from a certain point of view. The data found that students were able to evaluate credible information and what factors could influence it. However, it still needs a lot of practice at this stage because of the confusion in drawing conclusions on the arguments that are obtained.

\section{e) Explanation Skills}

Explanation skills are skills that provide an explanation of information using evidence, concept criteria and methods. Students are asked to make precise and accurate statements as a result of analysis, evaluation and inference. Students present concepts and consider them to get improvements from deficiencies. Students are able to assess how the author presents information in order to reveal the subjectivity or objectivity of the author. The next stage, students are able to justify and reject the way of presenting the information used by the author. At this stage, the result is that students are asked to make an idea to accept or reject the opinion presented by the author.

It was found that students were able to reject or believe the opinions presented on social media. All students are able to pass this stage because they have gathered true and false evidence. So, students can get the right statement to reject or accept arguments in information on social media.

\section{f) Self-Regeneration Skills}

Self-relegation skills are the skills of a person to be able to monitor cognitive activities through self-analysis and evaluation. Students reflect on their personal views and reveal factors that influence themselves to accept or reject information conveyed on social media. The indicator that can be used is to formulate solutions by overcoming one's own thoughts and actions based on dominant prejudice. The data showed that some students were able to assess themselves by finding solutions in overcoming their own thoughts. Other students are still not able to self-evaluate, only able to sort out and receive the information they get, but have not been able to self-correct through the formulation of inclusion in their respective thoughts.

Developing reading activities through the reading process is able to form critical reading skills. Readers are able to judge the correctness of information and increase critical responses in terms of reading. By carrying out the process of critical reading on social media that preaches things related to Islam, it is able to minimize the circulation of fake news in the community. Tell when the information can be justified, do not convey it when the information is not known to be true. 


\section{Conclusion}

Students have a critical mindset so that they are able to carry out the process of critical reading. Students are able to identify news that is not necessarily true, so that it can be used in everyday life. Critical readiing skill may help suppress suppress the spread of fake news in the community. Various social media have been able to increase students' interest in reading. Social media is a tool that is able to disseminate information to readers so that it is able to build student criticism in understanding texts that have Islamic values. Some students were able to critically analyze information from social media related to Islamic values. However, some information is sometimes received without going through a critical reading process.

\section{References}

[1] Rowe, J .: Student use of social media: When should the university intervene? Journal of Higher Education Policy and Management, 36 (3), 241-256. (2014).

[2] Siddiqui, Shabnoor and Tajinder Singh: Social Media its Impact with Positive and Negative Aspects. International Journal of Computer Applications Technology and Research. Volumes 5- Issue 2, 71 - 75. (2016)

[3] Agustina. : Pembelajaran Keterampilan Membaca. (Buku Ajar). Padang: FBSS UNP. (2008)

[4] Nurhadi: Basics of Reading Theory. Malang: State University of Malang. (2009)

[5] Ahuja, P. \& G. C. Ahuja .: How to Read Effectively and Efficiently. Translated by Tina Martiani. Bandung: Penerbit Kiblat. (2010).

[6] Sulthan, Muhammad and S. Bekti Istiyanto: Model Literasi Media Sosial Mahasiswa. ASPIKOM Journal, Volume 3 Number 6. (2019).

[7] Tan, Jennifer Pei-Ling, et.al .: Learner Dashboards a Double-Edged Sword? Students' Sense-Making of a Collaborative Critical Reading and Learning Analytics Environment for Fostering 21st-Century Literacies. Journal of Learning Analytics, 4 (1), 117-140. Download in https://learninganalytics.info/index.php/JLA/article/view/5156/5816. (2017).

[8] Ganggi, Roro Isyawati Permata: Materi Pokok dalam Literasi Media Sosial sebagai salah Satu Upaya Mewujudkan Masyarakat yang Kritis dalam Bermedia Sosial. ANUVA Volume 2 (4). Download in http://ejournal.undip.ac.id/index.php/anuva. (2018).

[9] Ibda, Hamidulloh: Gerakan Metal (Membaca Artikel) untuk Meningkatkan Kemampuan Membaca Kritis Guru MI. MAGISTRA. Volume 8 Number 1. Download in

https://www.publikasiilmiah.unwahas.ac.id/index.php/MAGISTRA/article/viewFile/19 84/2604. (2018).

[10] Ghofur, Abdul and Nahdia Rupawanti Basuki Raharjo: Peningkatan Kemampuan Berfikir Kritis Mahasiswa Melalui Pendekatan 5E dan SETS Berbantu Aplikasi Media Sosial. JINoP (Jurnal Inovasi Pembelajaran), Vol. 4 no. 2. Download in http://ejournal.umm.ac.id/index.php/jinop/article/view/6678. (2018).

[11] Facione, P.A .: Critical Thinking: What It Is and Why It Counts (Sixth Edition). California: Measurement Reason LCC and Insight Assessment. Fairclough, N. 1989. Language and Power. Translation by Indah. 2015. 